Article

\title{
An Acetylenic Alkaloid from the Calcareous Sponge Leucetta sp.
}

\section{Idam Hermawan ${ }^{1}$, Nicole J. de Voogd ${ }^{2}$ and Junichi Tanaka ${ }^{1}{ }_{*}$}

1 Department of Chemistry, Biology and Marine Science, University of the Ryukyus, Nishihara, Okinawa 903-0213, Japan; E-Mail: damz_98@yahoo.com

2 Netherlands Centre for Biodiversity, Naturalis, PO Box 9517, 2300 RA Leiden, The Netherlands; E-Mail: Nicole.devoogd@ ncbnaturalis.nl

* Author to whom correspondence should be addressed; E-Mail: jtanaka@ sci.u-ryukyu.ac.jp; Tel.: +81-98-895-8560; Fax: +81-98-895-8565.

Received: 9 February 2011; in revised form: 28 February 2011 / Accepted: 17 March 2011 / Published: 21 March 2011

\begin{abstract}
A new acetylenic alkaloid was isolated from the sponge Leucetta sp. The structure was established by analyzing spectroscopic data. The alkaloid showed cytotoxicity $\mathrm{IC}_{50} 2.5 \mu \mathrm{g} / \mathrm{mL}$ against NBT-T2 cells.
\end{abstract}

Keywords: sponge; acetylene; alkaloid; cytotoxicity

\section{Introduction}

More than 8000 species of sponges have been recorded from intertidal to deep oceanic floors, from tropical to polar regions, and from marine to freshwater environments [1]. The majority of sponges prefer to grow in shallow warm waters such as coral reefs. Since coral reef sponges have been major subjects from an early stage of marine natural products study, they are recognized as the most prolific sources of diverse bioactive secondary metabolites among macrobenthos [2]. However, dereplication has become an increasingly major issue in natural product chemistry as it is common to encounter known molecules probably reflecting the fact that many overlapping specimens have been examined. To overcome this problem and to increase the diversity of source organisms, we collected sponges in a coral reef twilight zone (50-100 m), where the depth is too deep for conventional scuba diving and the fauna there have not been well examined. A few examples from the zone include seragamides [3] and a unique fatty acid [4]. In this short note, we describe a structure of a new cytotoxic acetylenic alkaloid from a sponge collected in the zone. 


\section{Results and Discussion}

The small sponge was extracted with acetone and its lipophilic portion showing cytotoxicity at $5 \mu \mathrm{g} / \mathrm{mL}$ was subjected to chromatographic separation to give compound 1 ( $0.088 \%$ from sponge). Compound 1 was found to have a molecular formula as $\mathrm{C}_{19} \mathrm{H}_{31} \mathrm{NO}$ indicating five degrees of unsaturation, which can be explained by the presence of two substituted acetylenes $\left(\delta_{\mathrm{C}} 65.1 \mathrm{~s}, 71.9 \mathrm{~s}\right.$, $\left.78.1 \mathrm{~s}, 84.8 \mathrm{~s} ; 2334 \mathrm{~cm}^{-1}\right)$ and one cis double bond $\left(\delta_{\mathrm{H}} 5.44 \mathrm{brd}, J=10.8 \mathrm{~Hz}, 6.04 \mathrm{dt}, J=10.8,7.5 \mathrm{~Hz}\right.$; $\left.\delta_{\mathrm{C}} 107.5 \mathrm{~d}, 149.2 \mathrm{~d}\right)$. Other structural features include an $N$-methyl group $\left(\delta_{\mathrm{H}} 2.24 \mathrm{~s}(3 \mathrm{H}) ; \delta_{\mathrm{C}} 41.5 \mathrm{q}\right)$, a terminal ethyl group $\left(\delta_{\mathrm{H}} 1.01 \mathrm{t}(3 \mathrm{H}), 2.36 \mathrm{~m}(2 \mathrm{H})\right)$, a primary alcohol $\left(\delta_{\mathrm{H}} 3.58 \mathrm{t}(2 \mathrm{H}) ; \delta_{\mathrm{C}} 58.2 \mathrm{t}\right.$; $\left.3407 \mathrm{~cm}^{-1}\right)$, and nine methylenes $\left(\delta_{\mathrm{H}} 1.30-2.32,2.39 \mathrm{~m}(2 \mathrm{H}), 2.52 \mathrm{t}(2 \mathrm{H})\right)$. The primary alcohol group was coupled $(J=6.7 \mathrm{~Hz})$ to a methylene at $\delta_{\mathrm{H}} 2.52$, which showed HMBC correlation with the $N$-methyl group at $\delta_{\mathrm{H}} 2.24$ and also with another methylene at $\delta_{\mathrm{H}} 2.39$ indicating the presence of a tertiary amine with these substituents. The terminal ethyl group was connected to the double bond by observing COSY (H-13/H-14,15, H-14/H-15) and HMBC (H-13/C-15, H-15/C-13,14,16) cross peaks. This double bond was found to be conjugated to a diyne group connected to methylenes (H-13/C-11, H-14/C-12, H-8/C-9,10,11,12). By elucidating the remaining methylenes as a linear structural unit with $\mathrm{HMBC}$ (H-7/C-6,8,9, H-1/C-2,3, H-2/C-3), the whole structure was assigned as 2-(hexadec-13-ene-9,11-diynyl-methyl-amino)-ethanol (Figure 1).

A number of polyacetylenic molecules have been reported from marine sources [4-7], however, compound $\mathbf{1}$ is the first example of polyacetylene with an alkaloidal functionality from a marine sponge.

Figure 1. Structure of compound 1.

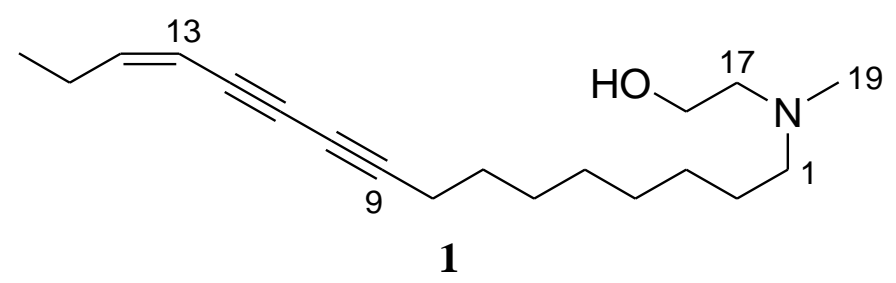

\section{Experimental Section}

\subsection{General Procedures}

FTIR spectrum was taken on a Varian FTS-3000 instrument. ${ }^{1} \mathrm{H},{ }^{13} \mathrm{C}$ and $2 \mathrm{D}$ (COSY, HSQC, HMBC) NMR spectra were obtained on a Bruker Avance III 500 spectrometer in $\mathrm{CDCl}_{3}$ with reference to an internal standard of TMS. Chemical shifts and coupling constants were given as $\delta$ and Hz. ESIMS was measured on a Jeol JMS-T100LP instrument.

\subsection{Animal Material}

The sponge, an undescribed Leucetta sp. (Figure 2, Leucettidae, Clathrinida, Calcarea), was collected at $50 \mathrm{~m}$ depth off Kume Island in Okinawa on September, 2009 and kept frozen until extraction. The sponge was identified by one of us (NJdV) and deposited at NCB Naturalis under the code RMNH POR 3927. The sponge is small, pink, pyriform and has one prominent osculum. The 
skeleton consists of regular triactines and tetractines densely and irregularly scattered throughout the ectosome and choanosome. The rays of the spicules range from 5-110 $\mu \mathrm{m}$, of which the smaller ones are juvenile forms.

Figure 2. The sponge Leucetta sp.

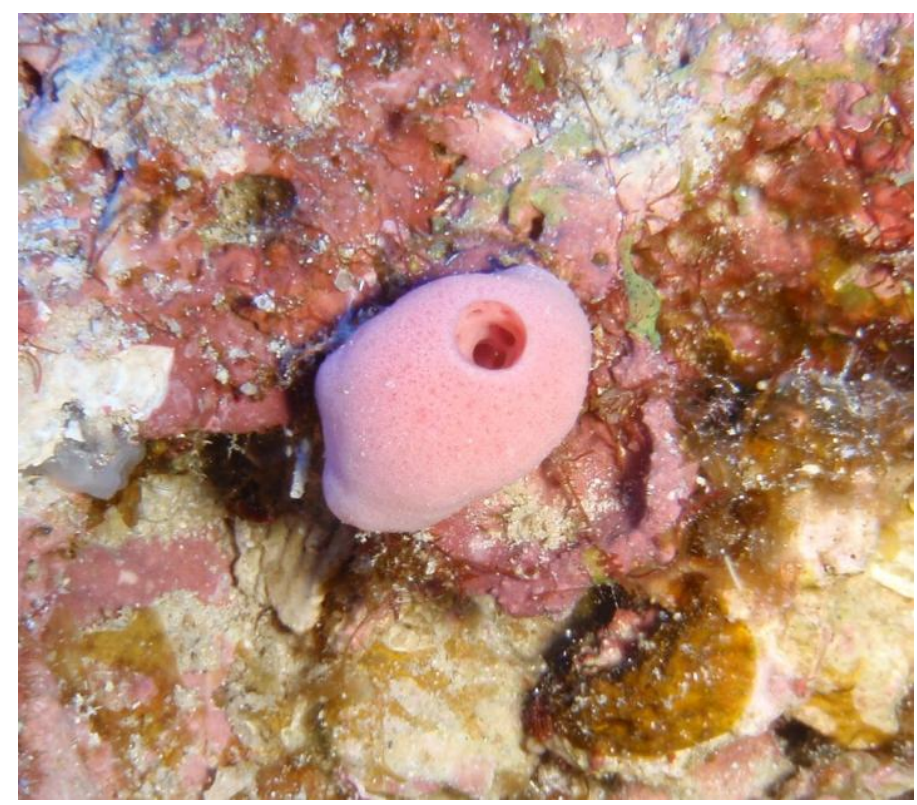

\subsection{Isolation of Alkaloid 1}

The sponge (wet, $3.54 \mathrm{~g}$ ) was extracted two times with acetone $(30 \mathrm{~mL})$. The resulting residue $(0.31 \mathrm{~g})$ was partitioned between EtOAc and water, and the organic layer was concentrated to give $14.7 \mathrm{mg}$ of the extract. It was then separated on a silica gel column with stepwise elution using $n$-hexane-EtOAc (2-1, 1-1, and 1-2), EtOAc-MeOH (1-5), and $\mathrm{MeOH}$ to give a total of 7 fractions. Fraction 7 contained $3.1 \mathrm{mg}(0.087 \%)$ of the alkaloid $\mathbf{1}$.

\subsection{Alkaloid 1}

Yellow oil, FTIR 3407, 2931, 2857, 2334, 1458, $1043 \mathrm{~cm}^{-1} .{ }^{1} \mathrm{H}$ and ${ }^{13} \mathrm{C}$ NMR: see Table 1. ESIMS obsd $m / z$ 290.24798, calcd for $\mathrm{C}_{19} \mathrm{H}_{32} \mathrm{NO}^{+} 290.24784$.

\subsection{Cytotoxicity Testing}

NBT-T2 cells (BRC-1370, purchased from Riken BioResource Center) were cultured in DMEM supplemented with $10 \%$ heat-inactivated fetal bovine serum and antimicrobials under standard protocol and seeded in $200 \mu \mathrm{L}$ wells. After preincubation $\left(37^{\circ} \mathrm{C}, 24 \mathrm{~h}\right)$, cells were exposed to graded concentrations of compound 1 in duplicate $\left(37{ }^{\circ} \mathrm{C}, 48 \mathrm{~h}\right)$. Then, the cells were treated with MTT solution $(15 \mu \mathrm{L}, 5 \mathrm{mg} / \mathrm{mL}$ in PBS) after removal of the medium and incubated for $3 \mathrm{~h}$. The residual formozan was dissolved in DMSO $(100 \mu \mathrm{L})$ and the absorbance was measured with a Tecan sunrise microplate reader at $560 \mathrm{~nm}$. The $\mathrm{IC}_{50}$ values were found by plotting the absorbance values against concentrations. The alkaloid showed cytotoxicity $\mathrm{IC}_{50} 2.5 \mu \mathrm{g} / \mathrm{mL}$ against NBT-T2 cells. 
Table 1. ${ }^{1} \mathrm{H}$ and ${ }^{13} \mathrm{C}$ NMR data for compound $\mathbf{1}$ in $\mathrm{CDCl}_{3}$.

\begin{tabular}{cclcc}
\hline $\mathbf{C \#}$ & $\boldsymbol{\delta}_{\mathbf{C}}{ }^{\mathbf{a}}$ & \multicolumn{1}{c}{$\boldsymbol{\delta}_{\mathbf{H}}(\mathbf{m u l t} ., \boldsymbol{J}$ in Hz) } & COSY & HMBC \\
\hline 1 & $57.7 \mathrm{t}$ & $2.39 \mathrm{~m}$ & $\mathrm{H}-2$ & $\mathrm{C}-2,3,17,19$ \\
2 & $27.2 \mathrm{t}$ & $1.46 \mathrm{~m}$ & $\mathrm{H}-1,3$ & $\mathrm{C}-3$ \\
3 & $27.2 \mathrm{t}$ & $1.30 \mathrm{~m}$ & $\mathrm{H}-2$ & $\mathrm{C}-1$ \\
4 & $29.3 \mathrm{t}$ & $1.30 \mathrm{~m}$ & & \\
5 & $29.0 \mathrm{t}$ & $1.30 \mathrm{~m}$ & & $\mathrm{C}-5$ \\
6 & $28.8 \mathrm{t}$ & $1.39 \mathrm{~m}$ & $\mathrm{H}-6,8$ & $\mathrm{C}-6,8,9$ \\
7 & $28.2 \mathrm{t}$ & $1.53 \mathrm{~m}$ & $\mathrm{H}-7$ & $\mathrm{C}-9,10,11,12$ \\
8 & $19.6 \mathrm{t}$ & $2.32 \mathrm{~m}$ & & \\
9 & $84.8 \mathrm{~s}$ & - & & \\
10 & $65.1 \mathrm{~s}$ & - & & $\mathrm{C}-11,15$ \\
11 & $78.1 \mathrm{~s}$ & - & $\mathrm{H}-14,15$ & $\mathrm{C}-10$ \\
12 & $71.9 \mathrm{~s}$ & - & $\mathrm{H}-13,15$ & $\mathrm{C}-13,14,16$ \\
13 & $107.5 \mathrm{~d}$ & $5.44 \mathrm{brd}, J=10.8 \mathrm{~Hz}$ & $\mathrm{C}-14,15$ \\
14 & $149.2 \mathrm{~d}$ & $6.04 \mathrm{dt}, J=10.8,7.5 \mathrm{~Hz}$ & $\mathrm{H}-13,14,16$ & $\mathrm{C}-1$ \\
15 & $24.1 \mathrm{t}$ & $2.36 \mathrm{~m}$ & $\mathrm{H}-15$ & $\mathrm{C}-17$ \\
16 & $13.3 \mathrm{q}$ & $1.01 \mathrm{t}, J=7.6 \mathrm{~Hz}$ & $\mathrm{H}-18$ & \\
17 & $58.7 \mathrm{t}$ & $2.52 \mathrm{t}, J=6.7 \mathrm{~Hz}$ & & \\
18 & $58.2 \mathrm{t}$ & $3.58 \mathrm{t}, J=6.7 \mathrm{~Hz}$ & & \\
19 & $41.5 \mathrm{q}$ & $2.24 \mathrm{~s}$ & &
\end{tabular}

\section{Conclusions}

A new acetylenic alkaloid 1 was characterized with spectroscopic methods. Together with our previous work [4], Calcareous sponges are still promising sources of unique bioactive molecules.

\section{Acknowledgements}

We would like to thank Takumi Iha for mass measurement, Novriyandi Hanif for the database search, Masayoshi Kondo for assistance with collection, and Steve Fabricant for English corrections. We appreciate PharmaMar for funding.

\section{References}

1. Cheng, L.S.; de Voogd, N.J.; Siang, T.K. A Guide to Sponges of Singapore; Singapore Science Center: Singapore, 2008.

2. Blunt, J.W.; Copp, B.R.; Munro, M.H.G.; Northcote, P.T.; Prinsep, M.R. Marine natural products. Nat. Prod. Rep. 2010, 27, 165-237 and previous reviews in this series.

3. Tanaka, C.; Tanaka, J.; Bolland, R.F.; Marriott, G.; Higa, T. Seragamides A-F, new actin-targeting depsipeptides from the sponge Suberites japonicus Thiele. Tetrahedron 2006, 62, 3536-3542.

4. Tianero, M.D.B.; Hanif, N.; de Voogd, N.J.; van Soest, R.W.M.; Tanaka, J. A new antimicrobial fatty acid from the Calcareous sponge Paragrantia cf. waguensis. Chem. Biodivers. 2009, 6, $1374-1377$. 
5. Aratake, S.; Trianto, A.; Hanif, N.; de Voogd, N.J.; Tanaka, J. A new polyunsaturated brominated fatty acid from a Haliclona sponge. Mar. Drugs 2009, 7, 523-527.

6. Matsunaga, S.; Okada, Y.; Fusetani, N.; van Soest, R.W.M. An antimicrobial C14 acetylenic acid from a marine sponge Oceanapia species. J. Nat. Prod. 2000, 63, 690-691.

7. Uno, M.; Ohta, S.; Ohta, E.; Ikegami, S. Callyspongins A and B: novel polyacetylene sulfates from the marine sponge Callyspongia truncata that inhibit fertilization of starfish gametes. J. Nat. Prod. 1996, 59, 1146-1148.

Samples Availability: As the original amount of compound $\mathbf{1}$ was small, we do not plan to distribute.

(C) 2011 by the authors; licensee MDPI, Basel, Switzerland. This article is an open access article distributed under the terms and conditions of the Creative Commons Attribution license (http://creativecommons.org/licenses/by/3.0/). 